\title{
TRADISI DETUNUHA: MEDIA PENINGKATAN INTERAKSI SOSIAL PADA MASYARAKAT MUNA DESA BANGKALI KABUPATEN MUNA
}

\author{
Oleh: Maliudin ${ }^{1}$, Lestariwati ${ }^{2}$, Nurmin Suryati $^{3}$, La Ode Hermin ${ }^{4}$ \\ ${ }^{1,2,3,4}$ Fakultas Ilmu Budaya Universitas Halu Oleo
}

\begin{abstract}
Abstrak
Penelitian ini membahas tentang bagaimana sebuah tradisi dalam masyarakat dapat menjadi sebuah wadah dalam meningkatkan interaksi sosial pada masyarakat Muna desa Bangkali. Hal ini dilakukan karena melihat bahwa desa Bangkali merupakan desa yang termasuk padat penduduknya sehingga perpecahan dan friksi mudah terjadi. Hal ini berpengaruh pada baik buruknya atau kuat dan lemahnya interaksi sosial dalam masyarakat. Salah satu solusi dalam menghindari friksi atau perpecahan tersebut adalah dengan tradisi detunuba. Tradisi detunuba merupakan tradisi membuat makanan tradisional dari ubi, kelapa dan gula merah yang melibatkan orang banyak. Penelitian ini bertujuan untuk mengetahui sejauh mana tradisi detunuba dapat menjadi media untuk meningkatkan interaksi masyarakat Muna Desa Bangkali, Kabupaten Muna. Hasil yang didapatkan bahwa pada proses tradisi detunuba pada masyarakat desa Bangkali dari awal sampai akhir selalu melibatkan banyak orang. Mereka saling membantu dan saling bekerjasama agar kegiatan dapat berjalan dengan lancar. Dalam bentuk-bentuk interaksi, semua proses yang terjadi masuk ke dalam kategori bentuk cooperation (kerjasama) dan joint-venture (usaha patungan).
\end{abstract}

Kata Kunci: Detunuha, Interaksi, Sosial Tradisi.

\section{PENDAHULUAN}

Sejak jaman dahulu, masyarakat Indonesia memiliki banyak cara untuk membangun sebuah interaksi yang baik antara satu dengan yang lainnya. Hal ini ini diwujudkan dalam berbagai dalam bentuk aktivitas sosial yang terangkum dalam unsur-unsur kebudayaan seperti tradisi labuhan di desa Tegal Sari Jawa Tengah (Widyatwati, 2012), tradisi nadran di daerah pesisir Indramayu, tradisi Alak Tau yang ada di sebagian besar daerah Jawa, tradisi marsialapari di Sumatera Utara, tradisi Ngayah di Bali, tradisi makan bajamba pada masyarakat Minangkabau, babacakan di Banten, dan lain-lain. Masyarakat Muna yang juga merupakan salah satu suku yang ada di Indonesia khususnya di Sulawesi Tenggara juga memiliki beberapa tradisi yang melibatkan interaksi orang banyak, diantaranya adalah detunuba. Detunuba berasal dari bahasa Muna yaitu de yang artinya melakukan/membuat dan tunuba yang artinya makanan yang terbuat dari ubi. Jadi detunuba artinya membuat makanan dari ubi. Proses pembuatannya harus dilakukan secara bergotong royong. Setiap tahun, masyarakat desa Bangkali selalu berusaha untuk melaksanakan kegiatan ini baik dalam kelompok yang besar maupun yang kecil. Ketika musim kemarau akan berakhir, maka ladang-ladang yang ditanami dengan ubi kayu segera dipanen. Kemudian hasil panen tersebut disiapkan untuk dibuat tunuha.

Sekilas dapat dikatakan bahwa masyarakat desa Bangkali merupakan masyarakat desa yang modern. Sebagian besar masyarakat telah mengenal teknologi. 
Rumah-rumah telah diisi dengan televisi compact disk, rice cooker, dispenser dan berbagai macam jenis tekhnologi yang lainnya. Untuk berkomunikasi pun hampir semua telah menggunakan gawai android. Keintiman-keintiman sosial sudah mulai berkurang. Hal ini lebih banyak terjadi pada mereka yang masih berusia muda. Mereka lebih banyak berdiam diri di dalam rumah dan jarang bersosialisasi dengan lingkungan sekitarnya. Mereka berinteraksi hanya pada kegiatan-kegiatan tertentu saja atau hanya dengan teman-teman sekolah yang akrab dengan mereka. Dengan melakukan penelitian terkait media interaksi melalui tradisi maka diharapkan hal tersebut dapat dijadikan sebuah alat bagi peningkatan interaksi sosial pada masyarakat Muna desa Bangkali.

Untuk memahami permasalahan di atas maka dibutuhkan sejumlah konsep dan teori tradisi dan interaksi sosial. Menurut Raho (2013) interaksi terdiri dari dua kata, yakni action (aksi) dan inter (antara) sehingga dapat dikatakan bahwa interaksi adalah suatu rangkaian tingkah laku yang terjadi antara dua orang atau lebih dari dua atau beberapa orang yang saling mengadakan respons secar timbal balik. Dalam defenisi lain, menurut Chaplin dikatakan bahwa (2011) bahwa interaksi merupakan satu relasi dua sistem yang terjadi sedemikian rupa sehingga kejadian yang berlangsung pada satu sistem akan mempengaruhi kejadian yang terjadi pada sitem lainnya atau dapat pula dikatakan bahwa interaksi adalah satu pertalian sosial antar individu sedemikian rupa sehingga individu yang bersangkutan saling mempengaruhi satu sama lainnya. Mahmudah (2010) menambahkan bahwa interaksi sosial dipengaruhi oleh beberapa faktor. Fakor-faktor tersebut adalah faktor imitasi, faktor sugesti, faktor identifikasi, dan simpati.

Interaksi sosial ini dapat berlaku dalam bidang apapun termasuk dalam bidang budaya dan tradisi. Dalam pengertian yang disampaikan oleh Pudentia (Nggawu, 2011) dikatakan kata tradisi berasal dari bahasa Latin, yaitu tradition yang berarti "diteruskan" atau "kebiasaan". Dalam pengertian yang paling sederhana adalah sesuatu yang telah dilakukan sejak lama dan menjadi bagian dari kehidupan suatu kelompok masyarakat, biasanya dari suatu negara, kebudayaan, waktu, atau agama yang sama. Hal yang paling mendasar dari tradisi adalah adanya informasi yang diteruskan dari generasi baik tertulis maupun lisan. Tanpa adanya hal itu, suatu tradisi akan punah.

\section{METODE PENELITIAN}

Penelitian ini merupakan jenis penelitian kualitatif deskriptif, yakni bagaimana menganalisis data yang ada dengan berlandaskan teori dan konsep dalam bentuk deskriptif. Lokasi yang dijadikan sebagai tempat penelitian adalah desa Bangkali Kabupaten Muna. Pemilihan lokasi tersebut karena masyarakatnya masih melaksanakan tradisi detunuha setiap tahunnya. Informan yang dituju sebagai sumber data adalah para tokoh masyarakat, tokoh adat dan mereka yang banyak mengetahui tentang objek penelitian. Data penelitian dikumpulkan dengan cara pengamatan, wawancara, dan didokumentasikan. Setelah data didapatkan maka data tersebut akan 
dianalisis dengan menggunakan konsep-konsep interaksi sosial.

\section{PEMBAHASAN}

Desa Bangkali merupakan desa yang cukup padat penduduknya. Menurut data BPS tahun 2019 dengan luas 4 H desa ini dapat didiami oleh 1762 jiwa. Sebagian besar dalam 1 petak tanah yang luasnya kurang lebih 50 x $50 \mathrm{~m}$ dapat ditempati oleh beberapa rumah dan keluarga. Jika dirata-ratakan jarak antar rumah yang satu dengan rumah yang lain hanya berkisar antara 1-3 m. Bahkan ada beberapa rumah yang hampir berdempetan satu sama lain sehingga tidak ada celah untuk dapat dilewati orang. Pada sebagian orang hal ini menguntungkan, karena semakin dekat rumah seseorang maka hubungan kekeluargaan pula semakin dekat. Akan tetapi pada sebagian orang lain pula hal ini merupakan penyebab terjadinya friksi atau perpecahan. Hal ini berpengaruh pada baik buruknya atau kuat dan lemahnya interaksi sosial dalam masyarakat. Menurut Slamet (2004) terdapat beberapa faktor yang memengaruhi interaksi sosial. Faktor-faktor tersebut adalah situasi sosial, kekuasaan norma kelompok, tujuan pribadi masing-masing individu, dan penafsiran sosial. Lebih mendetail lagi, Soekanto (2006) mengatakan bahwa terhambatnya proses interaksi dapat disebabkan oleh beberapa hal, yakni perasaan takut berkomunikasi dan adanya pertentangan pribadi.

\section{Proses Tradisi Tunuha}

Untuk mengurangi potensi terhambatnya interaksi sosial dalam masyarakat maka ada berbagai cara yang dilakukan baik itu secara internal maupun eksternal. Masyarakat selalu memiliki cara untuk mengatasi terhambatnya sebuah interaksi sosial. Masyarakat desa Bangkali pun juga memiliki cara dalam membangun dan menjaga hubungan interaksi sosialnya. Salah satunya adalah dengan menggiatkan acara-acara tradisi seperti tradisi detunuba. Detunuba adalah kegiatan membuat tunuba yakni makanan tradisional yang terbuat dari parutan ubi dicampur dengan kelapa dan gula merah lalu tempatkan ke dalam bambu kemudian bambu tersebut dibakar semalaman ke dalam bara api di dalam tanah. Yang menarik dari kegiatan membuat makanan tradsional ini adalah pelibatan orang yang lebih dari 1 orang mulai dari awal pembuatan sampai selesai. Adapun proses-proses tersebut meliputi:

1. Tahap Persiapan

Pada bulan September, Oktober, November atau Desember awal setiap tahunnya, masyarakat desa Bangkali mulai bersiap-siap membersihkan kebun. Di masa ini biasanya, ubi-ubi kayu yang merupakan tanaman palawija terakhir di kebun akan siap dipanen. Satu sama lain di antara mereka mulai mencari informasi atau saling berkonfirmasi dimana akan diadakan tunuba. Menurut Wa Ode Ndoaka bahwa waktu untuk melaksanakan tradisi detunuba adalah sekitar bulan September, Oktober, November dan Desember. Pada bulan-bulan yang dimaksud tanah untuk tempat memanggang tunuha dalam kondisi sangat baik. Jika sebelum bulan-bulan tersebut, maka tunuha bisa jadi tidak masak. Tanah masih agak lembab karena hujan yang masih sering turun. 
Pada musim ini masyarakat mulai merencanakan untuk membuat tunuha. Jika telah terdapat warga yang bersedia akan melaksanakan tradisi detunuba maka masyarakat di sekitar si empunya kegiatan akan mendafatar untuk ikut kegiatan tersebut. Pendaftaran ini sangat penting karena hal ini difungsikan untuk mengetahui sebesar apa lubang yang akan digali. Orang-orang yang mendaftar pada acara ini biasanya bukan saja dari tetangga sekitar tetapi juga keluarga yang tinggalnya jauh dari desa Bangkali seperti Watopute, desa Dana, dan desa-desa lainnya bahkan keluarga yang berasal dari kota atau bahkan sampai di luar Kabupaten Muna itu sendiri seperti Kendari. Orang-orang jauh ini akan menitip kepada keluarganya dan nantinya jika sudah masak maka tunuba akan dikirimkan ke rumah mereka. Pendaftaran dilakukan dengan cara penyampaian secara lisan atau non formal.

Setelah pendaftaran dilakukan maka si empunya acara akan memanggil modhi untuk mempersiapkan lubang akan akan dijadikan tempat memanggang tunuba. Lokasi yang dipilih merupakan hasil kesepakatan beberapa pihak dalam keluarga si pemilik acara. Setelah penetapan lokasi, lalu masyarakat mulai bekerja sama unuk mempersiapkan apa-apa saja yang dibutuhkan di tahap awal ini. Para warga laki-laki mulai mempersiapkan perlengkapan untuk pelaksanaan detunuba seperti batu dan kayu. Mereka harus mengumpulkan batu dan kayu sebanyak yang diperlukan.

2. Tahap Pelaksanaan

Pada tahap pelaksanaan terbagi menjadi dua kelompok, yakni kelompok ibuibu atau perempuan yang bertugas mempersiapkan adonan tunuba dan kelompok bapak-bapak yang bertugas untuk mempersiapkan lubang, bambu, kayu dan batu dan proses selanjutnya.

a. Kelompok Ibu-Ibu atau Perempuan

Dalam pembuatan tunuba, hampir semua pihak ikut terlibat baik bapak-bapak maupun ibu-ibu. Masing-masing memiliki tugas yang berbeda. Kelompok ibu-ibu atau para perempuan adalah membuat adonan tunuha. Bahan utama dari pembuatan tunuha adalah ubi kayu sedangkan bahan tambahan lainnya adalah kelapa, gula merah dan garam secukupnya. Akan tetapi seiring perkembangan zaman, masyarakat sering berkreasi dengan menambahkan mentega dan tepung. Akan tetapi ada juga yang disebut dengan tunuba kapute (tunuha berwarna putih). Tunuha berwarna putih ini dibuat hanya dari ubi kayu, garam dan kelapa. Jenis tunuba yang ini biasanya dibuat untuk menjadi makanan pokok pengganti nasi yang dimakan dengan ikan dan sayur. Sebelum tahun 2000 an, terkadang anak-anak kecil di desa Bangkali bermain katutunuba (tunuha kecil-kecilan). Mereka menggali ubi jalar dan ubi kayu lalu menyimpannya ke dalam tanah yang sudah panas karena bara api, lalu menutupnya dengan tanah dan daun-daunan.

Setelah bahan-bahan tersedia, maka ubi kayu dibersihkan lalu diparut pada pukul 13.00 ke atas. Hal ini dilakukan agar hasil parutannya tidak mudah basi atau berbuih. Kadang-kadang bagi masyarakat yang tidak ingin capek, mereka memarut ubi kayu dengan menggunakan mesin parutan. Akan harus tetap diperhatikan adalah waktu pemarutan ubi kayu. Jika menggunakan mesin parut maka diusahakan ubi 
kayu diparut sekitar jam 17.00 WITA. Jika parutan ubi telah sedia, maka parutan tersebut dicampur dengan bahan-bahan tambahan seperti gula merah, garam dan kelapa. Jika diinginkan maka kadang juga mereka menambahkan bawang merah, mentega dan tepung.

b. Kelompok Bapak-Bapak atau Laki-Laki

Selama proses pembuatan adonan tunuha oleh ibu-ibu, pihak bapak-bapak atau laki-laki mempersiapkan hal lain. Hal yang mereka siapkan adalah sebagian melakukan katidaki. Katidaki adalah proses penandaan atau pemberian patok untuk besar lubang yang akan digali. Katidaki dipimpin oleh modhi dan diawali dengan berdoa kepada Tuhan agar proses tradisi detunuha berjalan dengan baik dan lancar. Lalu para bapak-bapak atau laki-laki mulai menggali tanah yang sudah dipatok. Menurut Wa Ode Ndoaka dalam wawancara berikut ini :

"Kabewano kantobha maitu doukurue nekabharino sotumunubano, ane nobhari tumaino maka kawareno kantobha raamitere, ane mina nabhari sotumaino maka semitere bhahi semitere setanga"

Artinya:

"Luasnya lubang diukur berdasarkan banyaknya orang yang akan mengikuti tradisi detunuha. Jika banyak yang mendaftar maka diameternya adalah 2 meter, tetapi jika tidak banyak yang mendaftar maka paling panjang diameternya adalah antara $1-1,5$ m”. (wawancara 20 Oktober 2020).

Penggalian lubang dimulai pukul 03.00 WITA. Hal ini dilakukan karena proses penggalian lubang memakan waktu yang lumayan lama. Jika lubang diperkirakan cukup maka proses selanjutnya adalah peletakkan kayu pertama di atas galian oleh modhi dan dilanjutkan oleh yang lainnya. Kayu diletakkan dengan cara disusun berdempet karena di atas kayu akan diletakkan batu-batu yang telah dikumpulkan sebelumnya. Setelah itu kayu dan batu dibakar melalui celah lubang yang ada di bawahnya. Pembakaran kayu dan batu juga diawali oleh modhi dengan memperhatikan arah angin yang bertiup. Hal ini dilakukan agar nyala api searah dengan angin sehingga kayu dan batu mudah terbakar secara keseluruhan.

Selama proses pembakaran, sebagian bapak-bapak atau laki-laki mempersiapkan daun kumbou dan daun meware (lebar). Daun-daun tersebut mudah ditemukan di kebun-kebun warga. Jika kayu dan batu telah terbakar secara keseluruhan maka daun-daun di atas berfungsi untuk menutupi uap kayu dan batu agar hawa panasnya tidak keluar. Selain itu daun tersebut digunakan sebagai penutup bambu yang merupakan wadah adonan tunuba.

Hal lain yang dilakukan oleh para laki-laki adalah mempersiapkan bambu sebagai wadah adonan tunuba. Bambu yang dipilih adalah bambu lumayan tua agar bambu tidak mudah pecah. Setelah dibersihkan, bambu tersebut dibawa ke tempat ibu-ibu. Ibu-ibu mengambil bambu lalu memasukkan adonan yang telah siap ke dalam bambu. Setelah ibu-ibu mengisi adonan ke dalam bambu, lalu bambu ditutupi dengan daun-daun seperti yang dimaksudkan sebelumnya. Selanjutnya, masingmasing orang atau pemilik bambu mengikat bambu yang telah diisi dengan adonan 
tunuba secara berkelompok dan memberi tanda agar tidak tertukar dengan yang lainnya. Setelah itu, bambu tersebut dibawa ke tempat pembakaran. Hal ini terlihat

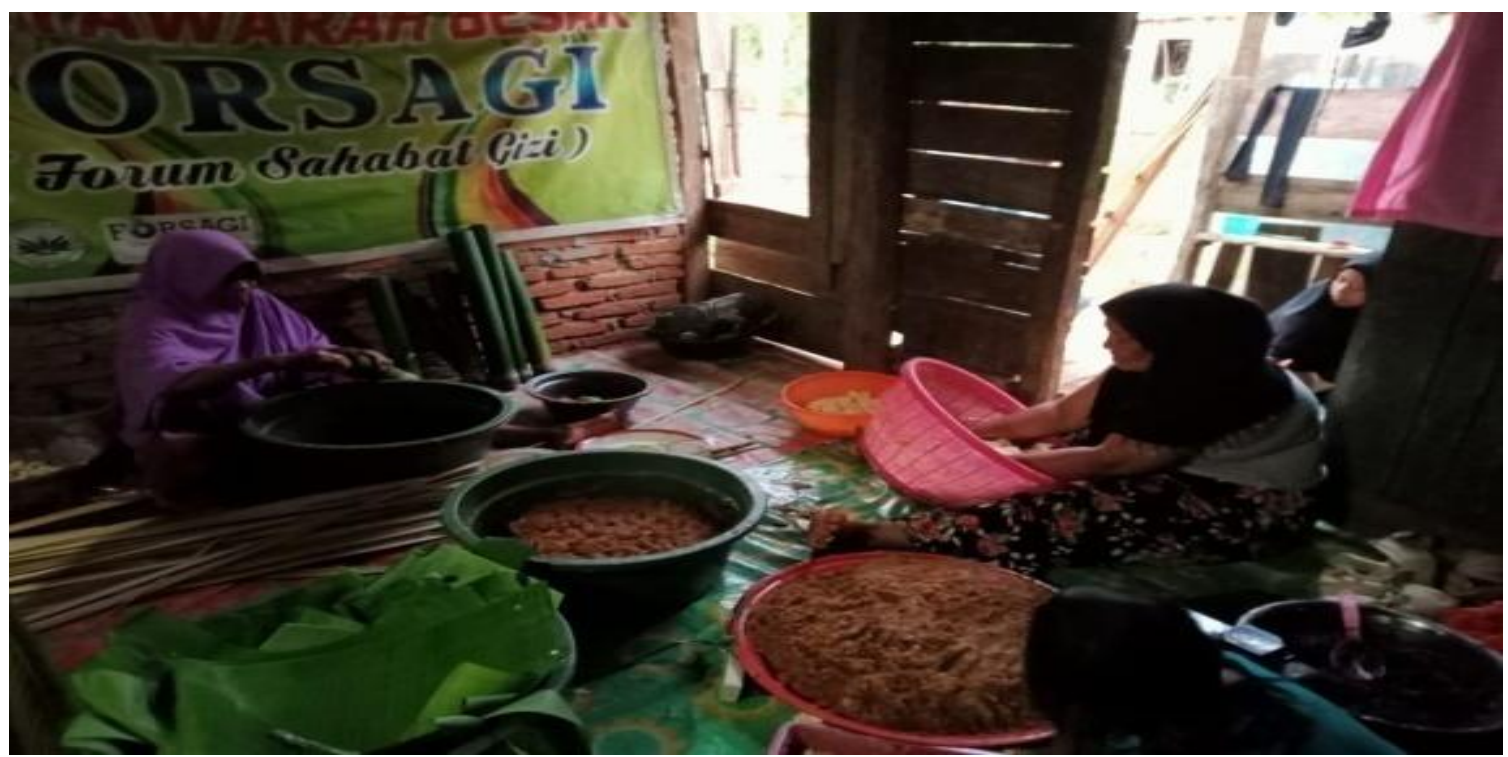

pada gambar berikut ini.

Gambar 1. Mempersiapkan Adonan Tunuba

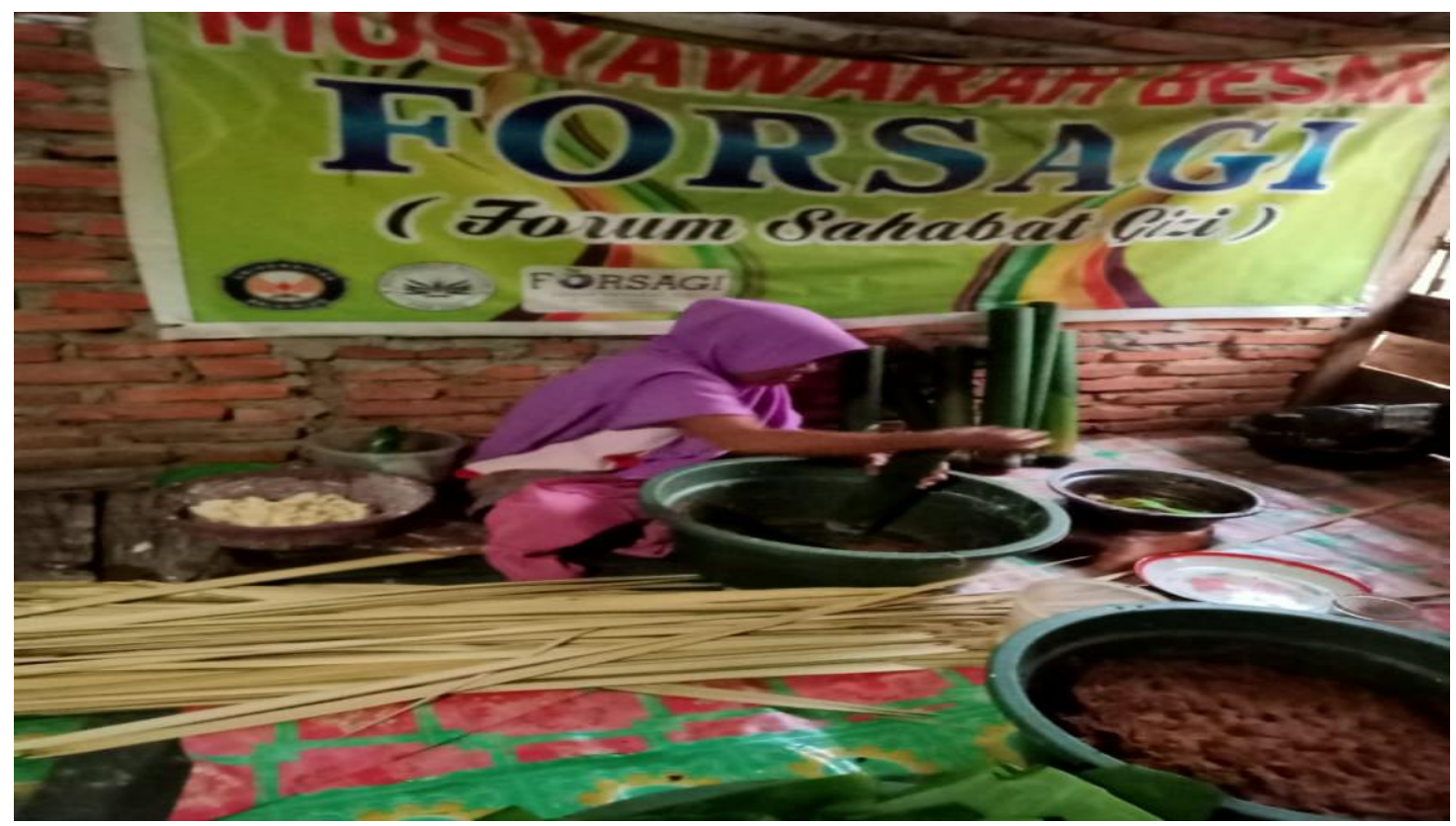

Gambar 2. Proses Memasukkan Adonan ke Dalam Bambu

Jika segalanya telah siap, maka satu persatu tunuba dimasukkan ke dalam lubang. Setelah semua tunuba dimasukkan, maka tunuba tersebut ditutup dengan bara, lalu dilapisi lagi dengan daun kumbou dan daun meware dan selanjutnya lubang ditimbun dengan tanah. Tunuha akan dibiarkan di dalam lubang tanah selama semalam. Besok paginya timbunan tunuba akan siap dibuka. Hal ini terlihat pada gambar berikut ini. 


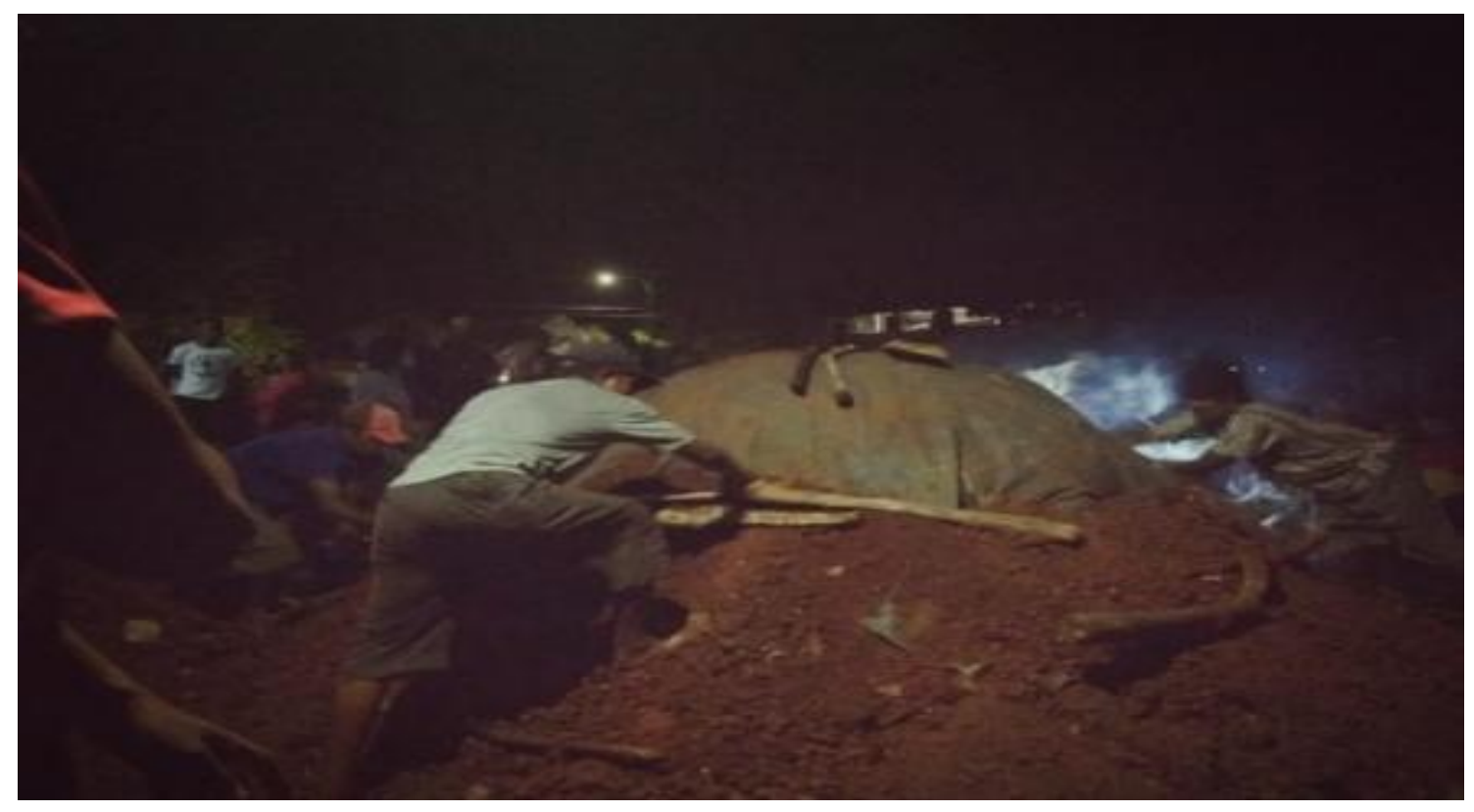

Gambar 3. Proses Menutup Lubang Tanah yang Berisi Tunuha.

\section{Tahap Akhir}

Setelah semalaman tunuha dibiarkan di dalam lubang tanah, pagi harinya, gundukan tanah siap untuk dibuka. Modhi dipersilahkan untuk membaca doa terlebih dahulu sebagai wujud rasa syukur kepada Allah SWT, Tuhan yang Maha Kuasa atas hasil tani selama setahun. Dalam doanya juga diharapkan agar masyarakat dijauhkan dari marabahaya. Kemudian gundukan tanah dibuka dan masing-masing mengambil tunuba miliknya. Hal ini dapat terlihat pada gambar berikut ini.

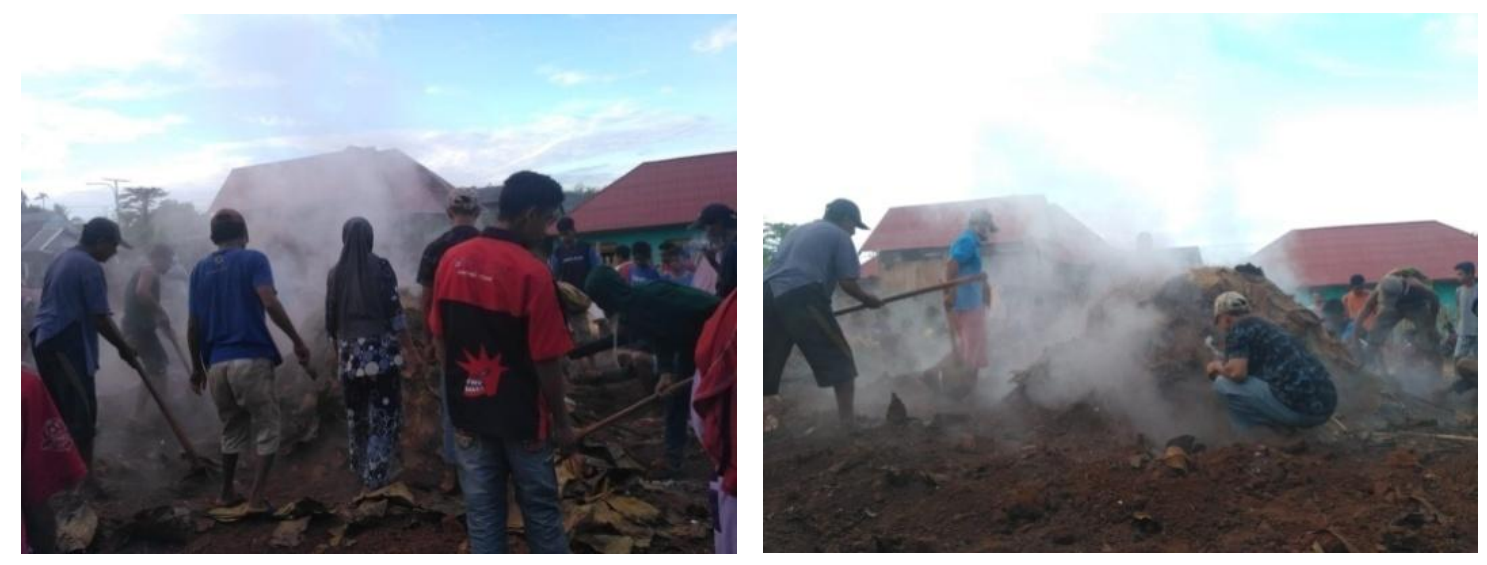

Gambar 4. Membuka Gundukan Tanah

\section{Interaksi Sosial dalam Tradisi Tunuha}

Melihat proses pembuatan Tunuba di atas maka dapat dilihat bahwa sejak awal sampai akhir selalu melibatkan banyak orang. Bahkan dalam menyelesaikan tugas- 
nya, orang-orang seakan-akan terbagi menjadi dua kelompok yakni kelompok bapakbapak atau laki-laki dan kelompok ibu-ibu atau perempuan. Hal ini terjadi secara natural. Masing-masing paham akan tugasnya sendiri-sendiri. Kelompok bapakbapak atau laki-laki bertugas untuk pekerjaan yang kasar-kasar seperti menggali lubang tunuba, mengangkut kayu dan batu, membakar kayu dan batu, mengambil bambu di dalam kebun serta memasukkan tunuba ke dalam tanah. Di lain pihak ibuibu mengerjakan adonan tunuba, pekerjaan yang tidak terlalu berat. Masing-masing kelompok pun saling bantu membantu satu sama lain sehingga selama proses pembuatan tunuba, interaksi terus dibangun bahkan sampai selesai acara tunuba. Contohnya adalah masyarakat sering memberi tunuba kepada tetangga yang tidak sempat ikut atau saling bertukar tumuha antara satu dengan yang lainnya. Dalam jenis interaksi sosial, hal ini dapat disebut dengan interaksi sosial asosiatif coorperation atau kerjasama. Menurut Soekanto (2010), kerjasama terbentuk karena masyarakat menyadari bahwa mereka mempunyai kepentingan-kepentingan yang sama sehingga sepakat untuk bekerjasama dalam mencapai tujuan bersama. Berdasarkan pelaksanaannya terdapat empat bentuk kerjasama, yaitu bargaining (tawar-menawar), cooptation (kooptasi), koalisi dan joint-venture (usaha patungan).

Bargaining pada tradisi detunuha dapat terlihat pada pendaftaran siapa saja yang akan mengikuti acara dan siapa yang akan menjadi si empunya acara. Kadang-kadang jika sudah musim tunuha, para warga saling melempar wacana atau isu kepada yang lainnya. Terkadang mereka menawarkan isu tersebut kepada mereka yang dianggap mapan dan mudah bersosialisasi dengan masyarakat. Jika isu tersebut disambut maka akan berlanjut pada proses selanjutnya.

Selanjutnya bentuk yang lain juga akan bisa terjadi pada kegiatan. Bentuk yang dimaksud adalah bentuk joint-venture (usaha patungan). Pada poin ini terlihat pada usaha warga dalam beberapa hal. Misalnya adalah penentuan lokasi pemanggangan tunuba. Kadang-kadang lokasi pemanggangan tunuba tidak berada di lokasi si empunya acara. Hal ini tergantung kesepakatan para warga, biasanya ada yang menawarkan lahannya untuk dijadikan lokasi atau biasanya juga lahan yang digunakan adalah milik si empunya acara. Hal ini terlihat pada kegiatan detunuba bulan Oktober tahun 2020. Pada saat itu Wa Ode Hadi bertindak sebagai si empunya acara. Oleh karena itu hampir sebagian besar kegiatan berpusat di kediaman Wa Ode Hadi walaupun sebagian yang lain juga membuat adonannya sendiri di rumah dengan anggota keluarganya. Akan tetapi lahan yang digunakan untuk pemanggangan tunuha tidak berada di tempatnya Wa Ode hadi. Lokasinya terdapat di depan rumahnya yang bukan merupakan lahan Wa Ode Hadi sendiri. Sebagai tuan rumah, Wa Ode Hadi memiliki tugas untuk memanggil modhi dan mengkoordir orang segala sesuatunya dapat terpenuhi. Pada peristiwa lain pula, terlihat bapak-bapak memberikan bambu kepada mereka yang kekurangan bambu sebagai wadah adonan tunuha. Di lain pihak pula para ibu-ibu berbagi peran dalam mempersiapkan bahan misalkan ada yang membawa gula, ada yang membawa ubi dan ada yang membawa kelapa. 
Peran yang terbagi-bagi ini dalam hubungannya terkait bentuk interaksi-interaksi sosial bisa dikatakan sebagai joint-venture.

\section{PENUTUP}

Dalam kehidupan bermasyarakat sering terjadi perbedaan dan friksi. Perbedaan dan fiksi ini dapat ditimbulkan oleh apa saja, bisa secara internal maupun secara eksternal. Hal ini bisa menjadi penyebab terhambatnya interaksi antar sesama. Terdapat banyak cara yang dilakukan oleh masyarakat untuk membangun interaksiinteraksi kepada sesama. Masyarakat desa Bangkali dalam membangun interaksinya adalah salah satunya dengan kegiatan tradisi. Kegiatan tradisi tersebut diantaranya adalah tradisi detunuba. Dalam proses detunuha dari awal sampai akhir selalu melibatkan banyak orang. Mereka saling membantu dan saling bekerjasama sehingga menghasilkan interaksi yang baik. Dalam bentuk-bentuk interaksi, semua proses yang terjadi masuk ke dalam kategori bentuk cooperation dan joint-venture.

\section{DAFTAR PUSTAKA}

Chaplin, J.P. (2011). Kamus Lengkap Psikologi. Jakarta: PT Raja Grafindo Persada.

Creswell, J. W. (2014). Penelitian Kualitatif dan Desain Riset. Yogyakarta: Pustaka Pelajar.

Elly M. S. \& Usman Kolip. (2011). Pengantar Sosiologi. Pemahaman Fakta dan Gejala Permasalahan Sosial: Teori, Aplikasi, dan Pemecahannya. Jakarta: Kencana

Erikson, Erik. 2010. Childhood and Society. Yogyakarta: Pustaka Pelajar.

La Ode Nggawu. (2011). Tuturan Lisan pada Tahap defenagho Tungguno Karete Dalam Perkawinan Masyarakat Muna di Kota Kendari. Kendari: Kantor Bahasa Provinsi Sulawesi Tenggara.

Mahmudah, Siti. (2010). Psikologi Sosial Sebuah Pengantar. Malang:UIN Malang Press.

Moleong, Lexy J. (2010). Metodologi Penelitian Kualitatif. Bandung: Remaja Rosdakarya.

Papalia, D.E., Olds, S.W., \& Feldman, R.D. (2009). Human Development. New York: McGraw-Hill Companies.

Poer \& Perry. (2013). Buku Ajar Fundamental Keperawatan: Konsep, Proses dan Praktek. Volume II. Edisi Revisi. Jakarta: EGC.

Raho, Bernard. (2004). Sosiologi Sebuah Pengantar. Surabaya: Sylvia.

Slamet, Santoso. (2004). Dinamika Kelompok Sosial. Jakarta: Bumi Aksara.

Soerjono, Soekanto. (2010). Sosiologi Suatu Pengantar. Jakarta: Rajawali Press.

Sugiyono. (2013). Metode Penelitian Kuantitatif Kualitatif dan $\mathrm{R}$ \& D. Bandung: Alfabeta.

Widyatwati, Ken. 2012. "Tradisi Labuhan Bagi Masyarakat Tegalsari Tegal”, dalam Tegalsari.pdf. Fakultas Ilmu Budaya Undip. Download tanggal 27 Juli 2020. 